\title{
IMPROVEMENT OF THE DURABILITY OF HEAT-TREATED WOOD AGAINST TERMITES
}

\author{
Solafa Salman ${ }^{1}$, Marie France Thévenon ${ }^{2}$, Anélie Pétrissans ${ }^{1}$, Stéphane Dumarçay ${ }^{1}$, \\ Kevin Candelier ${ }^{2}$, Philippe Gérardin ${ }^{1, \star}$
}

\begin{abstract}
Thermal modification is an attractive alternative to improve the decay durability and dimensional stability of wood. However, thermally modified wood is generally not resistant to termite attacks, limiting the field of application of such materials. One way to overcome this drawback is to combine thermal modification treatment with an additional treatment. One such treatment is the impregnation of a boron derivative associated with appropriate vinylic monomers, which takes advantage of the thermal treatment to polymerise these monomers for boron fixation. Using this strategy, we recently showed that an impregnation of borax ( 2 or $4 \%$ boric acid equivalent) dissolved in a $10 \%$ aqueous solution of polyglycerolmethacrylate followed by thermal treatment under nitrogen at $220^{\circ} \mathrm{C}$ protects wood from both termite and decay degradations, even after leaching. Additionally, wood samples treated with a $10 \%$ polyglycerolmethacrylate aqueous solution and subjected to thermal treatment at $220^{\circ} \mathrm{C}$ presented improved resistance to termites while avoiding boron utilization. Based on these results, we investigate the effect of impregnation with two types of vinylic monomers, which are already used in the presence of boron, followed by thermal treatments at different temperatures. We evaluate termite and decay durability of wood to evaluate if thermal modification associated with light chemical modification could be a solution for utilization of thermally modified materials in termite-infested areas.
\end{abstract}

Keywords: Chemical modification, decay, durability, Fagus sylvatica, Pinus sylvestris, Reticulitermes flavipes, thermal treatment.

\section{INTRODUCTION}

Wood thermal modification has been the subject of increasing interest over the last decades and is currently considered one of the most promising non-biocide alternatives to improving the performance of low natural durability wood species (Militz 2002, Esteves and Pereira 2009, Gérardin 2016). However, even if wood decay resistance and dimensional stability are improved, termite resistance is not sufficient to permit its use in termite-infested areas (Mburu et al. 2007, Shi et al. 2007, Surini et al. 2012, Sivrikaya et al. 2015). On the contrary, thermally modified wood is generally more susceptible to termite attacks than untreated wood (Sivrikaya et al. 2015, Salman et al. 2016). Termite

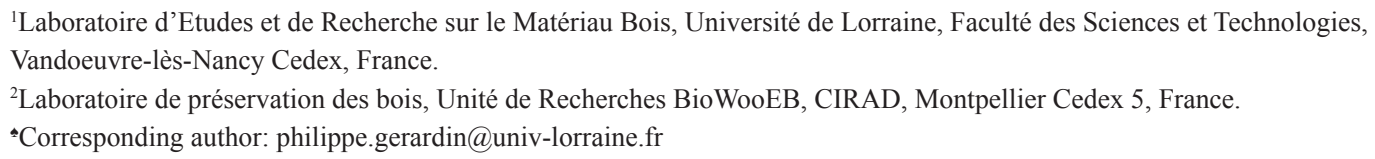


resistance improvements to thermally modified wood are crucial for future development of thermomodified materials. In this context, it was recently demonstrated that thermo-modified wood samples previously impregnated with boron in the presence of water soluble vinylic monomers, which are used to limit boron depletion, induced full protection of samples from termite attack and decay (Salman et al. 2014, Salman et al. 2016). Surprisingly, it was also observed that control samples treated with polyglycerolmethacrylate only and cured at $220^{\circ} \mathrm{C}$ were resistant to termites, while thermally modified blocks without treatment were strongly degraded. Considering the increase in interest in developing non-biocide wood protection treatments, it is critical to test mild chemical modifications based on the impregnation of vinylic monomers, followed by a thermal treatment that can lead to higher biological resistance. Even though previously developed chemical treatments, such as acetylation, DMDHEU or furfurylation, have claimed to enhance wood protection against termites (Wang et al. 2002, GascónGarrido et al. 2013), the advantages of the present approach is to reduce the chemical usage that is necessary to achieve wood protection. The aim of this paper is to evaluate different treatments based on thermal modification $\left(150,180,200\right.$ and $\left.220^{\circ} \mathrm{C}\right)$ of samples impregnated with a 5 or $10 \%$ aqueous solutions of two vinylic monomers, polyglycerolmethacrylate (PGMA) and polyglycerol/maleic anhydride adduct (AM/PG); we assess the durability of treated wood against different brown and white rot fungi as well as termites.

\section{EXPERIMENTAL}

\section{Materials}

Wood blocks ( $15 \mathrm{~mm}$ by $5 \mathrm{~mm}$ in cross section, $30 \mathrm{~mm}$ along the grain) of Scots pine sapwood (Pinus sylvestris L.) and beech (Fagus sylvatica) were used in this study. One hundred sixty-eight replicates were used for each treatment solution. Forty-two samples were used for each treatment temperature $\left(150,180,200\right.$ and $\left.220^{\circ} \mathrm{C}\right)$, and half of these samples were subjected to leaching. All chemicals were purchased from Fluka Sigma-Aldrich Chimie SARL (St Quentin Fallavier, France). Polyglycerol was furnished by Solvay as a mixture of compounds with an average molecular weight of $242(\mathrm{n} \sim 3)$.

\section{Synthesis of additives}

Maleic anhydride/polyglycerol adducts (MA/PG) and polyglycerol methacrylate (PGMA) were synthesized according to previously published procedures (Roussel et al. 2001, Soulounganga et al. 2003).

\section{Block impregnation}

Maleic anhydride/polyglycerol adducts and polyglycerolmethacrylate were dissolved with distilled water at 5 and $10 \%(\mathrm{~m} / \mathrm{m})$. Wood blocks were oven dried at $103^{\circ} \mathrm{C}$ and weighed $\left(\mathrm{m}_{0}\right)$. Wood samples were placed in a beaker inside a desiccator equipped with a two-way tape and subjected to vacuum at $5 \mathrm{mbar}$ for $15 \mathrm{~min}$. The treatment solution was then introduced into the beaker so that all blocks were completely covered by the solution. Blocks were kept immersed for $30 \mathrm{~min}$ at atmospheric pressure, removed from the impregnation solution, kept for 16 hours at ambient temperature, dried at $103^{\circ} \mathrm{C}$ for 48 hours and weighed $\left(\mathrm{m}_{1}\right)$. Weight percent gain (WPG) was calculated according to the following formula:

$$
\text { WPG }(\%)=100 \times\left(\mathrm{m}_{1}-\mathrm{m}_{0}\right) / \mathrm{m}_{0}
$$

where $\mathrm{m}_{0}$ is the initial anhydrous mass, and $\mathrm{m}_{1}$ is the anhydrous mass of treated wood samples. 


\section{Heat treatment}

Thermal modification was performed under nitrogen using a Carlo Erba GC oven. Samples were placed in a $500-\mathrm{mL}$ reactor for 20 hours at four different temperatures $\left(150,180,200\right.$ and $\left.220^{\circ} \mathrm{C}\right)$. The oven temperature was increased by $20^{\circ} \mathrm{C} \mathrm{min}^{-1}$ from ambient to final temperature. Weight loss due to thermal degradation $\left(\mathrm{WL}_{\mathrm{TT}}\right)$ was calculated according to the formula:

$$
\mathrm{WL}_{\mathrm{TT}}(\%)=100 \times\left(\mathrm{m}_{1}-\mathrm{m}_{2}\right) / \mathrm{m}_{1}
$$

where $m_{1}$ is the initial sample anhydrous mass before heat treatment, and $m_{2}$ is the anhydrous mass of the same sample after heat treatment.

\section{Leaching procedure}

Leaching was performed according to a procedure adapted from the NF X 41-569 standard (2014). Samples (twenty-one replicates) were immersed in $240 \mathrm{~mL}$ of distilled water and subjected to six leaching periods of increasing duration under continuous shaking at $20^{\circ} \mathrm{C}$. Water was replaced after each leaching period after 1 hour, 2 hours and 4 hours. Samples were then removed and air-dried for 16 hours. Additional leaching periods were conducted for 8 hours, 16 hours and 48 hours with water replacement between each. Blocks were finally dried at $103^{\circ} \mathrm{C}$ for 48 hours and weighed $\left(\mathrm{m}_{3}\right)$. Weight loss due to leaching was calculated as follows:

$$
\mathrm{WL}_{\mathrm{L}}(\%)=100 \mathrm{x}\left(\mathrm{m}_{2}-\mathrm{m}_{3}\right) / \mathrm{m}_{2}
$$

where $m_{2}$ is the pre-leaching initial anhydrous mass of wood samples after thermal treatment, and $\mathrm{m}_{3}$ is the anhydrous mass of the thermally modified wood samples after leaching.

\section{Thermogravimetric analysis}

Thermo gravimetric analysis (TGA) was performed on 10-mg samples under nitrogen using a Mettler Toledo TGA/DSC STARe system to investigate the thermal behaviour of impregnated wood and vinylic monomers. The analysis was run under nitrogen at a purge rate of $50 \mathrm{~mL} / \mathrm{min}$. Approximately $20 \mathrm{mg}$ of sample was heated from 25 to $220^{\circ} \mathrm{C}$ at a rate of $10^{\circ} \mathrm{C} / \mathrm{min}$.

\section{Decay tests}

Decay resistance was evaluated according to a procedure modified from EN 113 (1986) described by Bravery (1979). Pine samples were exposed to Coniophora puteana ((Schumacher ex Fries) Karsten, strain BAM Ebw. 15) and Poria placenta ((Fries) Cooke sensu J. Eriksson, strain FPRL 280), while beech wood samples were exposed to Coriolus versicolor ((Linneus) L. Quélet strain CTB 863 A) and Coniophora puteana (six replicates for each fungus). Sterile culture medium was prepared from malt $(40 \mathrm{~g})$ and agar $(20 \mathrm{~g})$ in distilled water $(1 \mathrm{~L})$ and placed in 9-cm diameter Petri dishes. After jellification of the medium, each Petri dish was inoculated with a small piece of mycelium of freshly grown pure culture and incubated for 2 weeks at $22^{\circ} \mathrm{C}$ and $70 \%$ relative humidity, providing full colonization of the surface by mycelium. All wood samples were autoclaved at $121^{\circ} \mathrm{C}$ for $20 \mathrm{~min}$.; three specimens (two treated and one control) were placed in each Petri dish. Each experiment was conducted in tripli- 
cate. Virulence controls were also performed on twelve specimens of untreated Scots pine and beech. Incubation was carried out for 16 weeks at $22^{\circ} \mathrm{C}$ under $70 \% \mathrm{RH}$ in a climatic chamber. Once the fungal exposure was complete, mycelium was removed, and specimens were weighed in order to evaluate their moisture content at the end of the fungal exposure. The specimens were then dried at $103^{\circ} \mathrm{C}$, and their final weight recorded. The moisture content at the end of the test (data not shown) and mass losses were determined. Mass loss (ML) was expressed as a percentage of initial oven-dry weight of the wood sample according to the formula:

$$
\mathrm{ML}(\%)=100 \times\left(\mathrm{M}_{0 \mathrm{OR} 2 \mathrm{OR} 3}-\mathrm{M}_{4}\right) / \mathrm{M}_{0 \mathrm{OR} 2 \mathrm{OR} 3}
$$

where $\mathrm{m} 4$ is the wood sample's final anhydrous mass after fungal exposure, $\mathrm{m} 0$ is the initial dry mass of the control sample, $\mathrm{m} 2$ is the anhydrous mass of PGMA or MA/PG impregnated (or not) wood samples cured at different temperatures before leaching, and $\mathrm{m} 3$ is the anhydrous mass of PGMA or MA/PG impregnated (or not) wood samples cured at different temperatures after leaching.

\section{Termite resistance tests}

Termite resistance was evaluated using Reticulitermes flavipes (ex. santonensis) termites using a non-choice test based on the guidelines of the European standard EN 117 (2013). Prior to the test, each sample was dried at $103^{\circ} \mathrm{C}$ in order to obtain its anhydrous initial weight $\left(\mathrm{m}_{0}\right.$, or $\mathrm{m}_{1}$ or $\left.\mathrm{m}_{2}\right)$. For each set of treatments, three replicates were tested for their resistance to termites. Each sample was placed in a 9-cm diameter Petri dish containing $40 \mathrm{~g}$ of Fontainebleau sand (4 volume of sand / 1 volume of deionized water). The samples were placed on plastic mesh in order to avoid water saturation. A total of 50 termite workers, one nymph and one soldier were then introduced to the sand. Fifteen controls of pine sapwood or beech were tested in the same manner. The Petri dishes were placed in a dark climatic chamber at $27^{\circ} \mathrm{C}$ with relative humidity $>75 \%$. After 4 weeks, the samples were removed and cleaned of sand, and the termite survival rate was calculated. The samples were dried at $103^{\circ} \mathrm{C}$, and their weight loss was calculated as a \% of initial weight.

\section{RESULTS AND DISCUSSION}

Tables 1 and 2 show weight percent gains obtained after impregnation with two vinylic monomers and in situ resin formation as well as the weight loss caused by thermal modification with or without subsequent leaching for pine and beech samples. 
Table 1. Weight change and standard deviation of pine sapwood samples impregnated with different additive concentrations and subjected to heat treatment at different temperatures.

\begin{tabular}{|c|c|c|c|c|c|}
\hline Additive & $\begin{array}{c}\text { Concentration } \\
(\%)\end{array}$ & $\begin{array}{l}\text { WPG } \\
(\%)\end{array}$ & $\begin{array}{l}\text { Temperature } \\
\left({ }^{\circ} \mathrm{C}\right)\end{array}$ & $\mathrm{WL}_{\mathrm{TT}}(\%)$ & $\mathrm{WL}_{\mathrm{L}}(\%)$ \\
\hline \multirow{4}{*}{ PGMA } & \multirow{4}{*}{5} & \multirow{4}{*}{$8,79 \pm 0,87$} & 150 & $1,36 \pm 0,29$ & $2,78 \pm 0,32$ \\
\hline & & & 180 & $3,54 \pm 0,65$ & $2,07 \pm 0,32$ \\
\hline & & & 200 & $7,74 \pm 1,16$ & $2,53 \pm 0,55$ \\
\hline & & & 220 & $13,95 \pm 2,07$ & $2,85 \pm 1,85$ \\
\hline \multirow{4}{*}{ PGMA } & \multirow{4}{*}{10} & \multirow{4}{*}{$16,89 \pm 1,49$} & 150 & $1,44 \pm 0,27$ & $3,7 \pm 1,54$ \\
\hline & & & 180 & $4,01 \pm 0,81$ & $2,53 \pm 0,65$ \\
\hline & & & 200 & $8,51 \pm 1,5$ & $2,45 \pm 0,38$ \\
\hline & & & 220 & $14,02 \pm 2,44$ & $3,57 \pm 0,32$ \\
\hline \multirow{4}{*}{$\mathrm{AM} / \mathrm{PG}$} & \multirow{4}{*}{5} & \multirow{4}{*}{$7,63 \pm 0,83$} & 150 & $1,33 \pm 0,23$ & $2,49 \pm 0,32$ \\
\hline & & & 180 & $3,49 \pm 0,46$ & $2,17 \pm 0,28$ \\
\hline & & & 200 & $6,92 \pm 0,96$ & $3,25 \pm 1,13$ \\
\hline & & & 220 & $11,34 \pm 2,1$ & $4,41 \pm 2,69$ \\
\hline \multirow{4}{*}{$\mathrm{AM} / \mathrm{PG}$} & \multirow{4}{*}{10} & \multirow{4}{*}{$16,14 \pm 1,45$} & 150 & $1,85 \pm 0,22$ & $3,9 \pm 0,41$ \\
\hline & & & 180 & $4,67 \pm 0,52$ & $2,04 \pm 0,47$ \\
\hline & & & 200 & $7,81 \pm 0,98$ & $4,24 \pm 1,76$ \\
\hline & & & 220 & $13,25 \pm 2,05$ & $5,01 \pm 2,84$ \\
\hline \multirow{4}{*}{-} & \multirow{4}{*}{-} & \multirow{4}{*}{-} & 150 & $0,46 \pm 0,21$ & $2,06 \pm 0,65$ \\
\hline & & & 180 & $2,11 \pm 1,29$ & $2,05 \pm 1,64$ \\
\hline & & & 200 & $5,55 \pm 1,28$ & $1,33 \pm 0,32$ \\
\hline & & & 220 & $9,12 \pm 1,1$ & $1,96 \pm 0,23$ \\
\hline
\end{tabular}


Table 2. Weight change and standard deviation of beech samples impregnated with different additive concentrations and subjected to heat treatment at different temperatures.

\begin{tabular}{|c|c|c|c|c|c|}
\hline Additive & $\begin{array}{c}\text { Concentration } \\
(\%)\end{array}$ & $\begin{array}{l}\text { WPG } \\
(\%)\end{array}$ & $\begin{array}{c}\text { Temperature } \\
\left({ }^{\circ} \mathrm{C}\right)\end{array}$ & $\mathrm{WL}_{\mathrm{TT}}(\%)$ & $\mathrm{WL}_{\mathrm{L}}(\%)$ \\
\hline \multirow{4}{*}{ PGMA } & \multirow{4}{*}{5} & \multirow{4}{*}{$5,76 \pm 0,56$} & 150 & $1,16 \pm 0,15$ & $2,07 \pm 0,23$ \\
\hline & & & 180 & $2,7 \pm 0,51$ & $1,35 \pm 0,19$ \\
\hline & & & 200 & $6,41 \pm 1,87$ & $1,19 \pm 0,27$ \\
\hline & & & 220 & $15,31 \pm 2,31$ & $0,9 \pm 0,42$ \\
\hline \multirow{4}{*}{ PGMA } & \multirow{4}{*}{10} & \multirow{4}{*}{$10,85 \pm 1,36$} & 150 & $1,44 \pm 0,22$ & $2,35 \pm 0,28$ \\
\hline & & & 180 & $3,8 \pm 0,63$ & $1,61 \pm 0,25$ \\
\hline & & & 200 & $8,83 \pm 1,66$ & $0,79 \pm 0,32$ \\
\hline & & & 220 & $14,81 \pm 2,87$ & $0,87 \pm 0,4$ \\
\hline \multirow{4}{*}{$\mathrm{AM} / \mathrm{PG}$} & \multirow{4}{*}{5} & \multirow{4}{*}{$5,35 \pm 0,74$} & 150 & $1,58 \pm 0,22$ & $2,33 \pm 0,47$ \\
\hline & & & 180 & $3,75 \pm 0,77$ & $1,81 \pm 0,52$ \\
\hline & & & 200 & $6,16 \pm 1,49$ & $2,20 \pm 0,63$ \\
\hline & & & 220 & $15,07 \pm 2,29$ & $1,7 \pm 0,99$ \\
\hline \multirow{4}{*}{$\mathrm{AM} / \mathrm{PG}$} & \multirow{4}{*}{10} & \multirow{4}{*}{$8,36 \pm 0,88$} & 150 & $1,83 \pm 0,23$ & $1,97 \pm 0,33$ \\
\hline & & & 180 & $4,43 \pm 0,95$ & $1,33 \pm 0,39$ \\
\hline & & & 200 & $9,31 \pm 1,82$ & $2,13 \pm 0,58$ \\
\hline & & & 220 & $13,21 \pm 2,25$ & $1,82 \pm 0,52$ \\
\hline \multirow{4}{*}{-} & \multirow{4}{*}{-} & \multirow{4}{*}{-} & 150 & $0,43 \pm 0,22$ & $1,34 \pm 0,23$ \\
\hline & & & 180 & $1,79 \pm 0,42$ & $1,36 \pm 0,18$ \\
\hline & & & 200 & $6,92 \pm 2,34$ & $1,28 \pm 0,4$ \\
\hline & & & 220 & $15,01 \pm 1,93$ & $1,44 \pm 0,46$ \\
\hline
\end{tabular}

Weight percent gains depend directly on vinylic monomer concentration in the impregnation solution. Increasing the concentration from 5 to $10 \%$ increases the WPG obtained by a factor of two, with pine wood being more easily impregnated than beech wood.

Weight loss after curing increases with treatment temperature. Samples cured at low temperature present weak weight losses, while those treated at $220^{\circ} \mathrm{C}$ present weight losses up to $15 \%$ depending on the impregnation solution and wood species. Independent of treatment, beech samples present generally higher weight losses compared to pine samples impregnated and cured in the same conditions; these results corroborate previous results on the effect of wood species during thermal treatment (Chaouch et al. 2010, Chaouch et al. 2013). For a given curing temperature, weight losses of impregnated samples are always higher than those of non-impregnated samples, indicating a higher susceptibility of resin treated samples to heat compared to untreated samples. This behaviour may be due to either a lower resin thermal stability or an effect of impregnated vinylic monomers or polymers resulting from the latter on wood thermal stability Therefore, the thermal stability of different vinylic monomers alone or impregnated in pine samples has been investigated using thermo gravimetric analysis (Figure 1). 


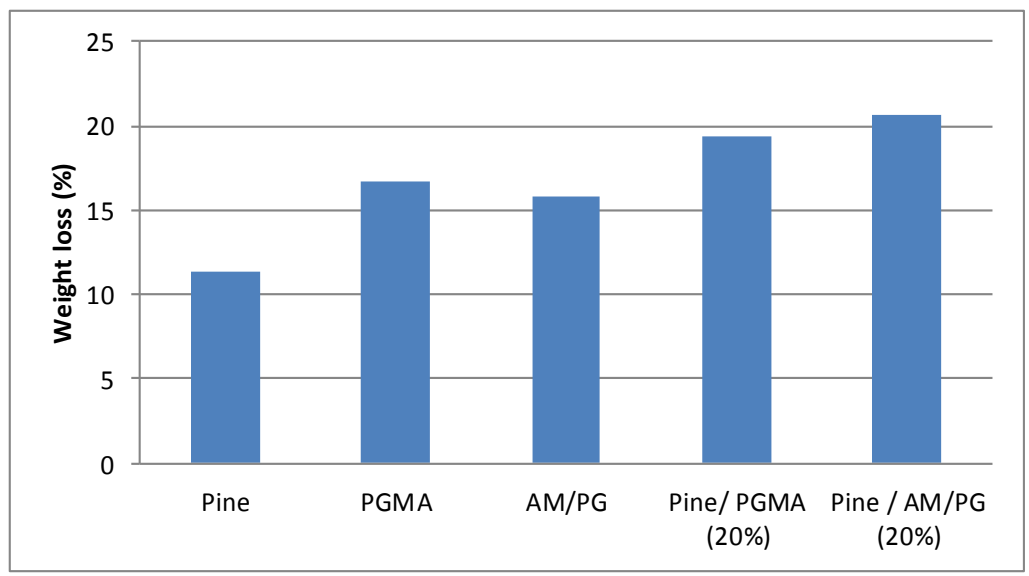

Figure 1. Weight losses recorded after 2 hours at $220^{\circ} \mathrm{C}$ by thermo gravimetric analysis.

According to results, resin is more sensitive to thermal degradation than pinewood as demonstrated by weight losses of 15,8 and $16,7 \%$ obtained for AM/PG and PGMA, respectively, compared to $11,3 \%$ for pine wood sawdust. The thermal behaviour of pine wood samples impregnated with a $20 \%$ aqueous solution of each vinylic monomer followed by polymerisation indicates a higher weight loss than with wood or resins alone. This behaviour shows the synergistic effect of wood and resins on the thermal stability of impregnated samples. Fixation of the two resins in wood was investigated after the leaching of the samples that were impregnated and cured at different temperatures (tables 1 and 2). Weight losses due to the leaching of extractives comprised between $1,33 \%$ and $2,06 \%$ for pine wood treated at different temperatures and between $1,28 \%$ and $1,44 \%$ for beech samples. At the same time, weight losses of pine samples treated with 5 or $10 \%$ of PGMA and cured at the different temperatures comprised between $2,07 \%$ and $3,47 \%$ indicating that a minimal amount of resin was leached from wood. No significant differences were observed between the different curing temperatures, indicating that polymerization of the vinylic monomers was effective from the lowest temperature of $150^{\circ} \mathrm{C}$. Similar results were obtained for pine samples impregnated with $\mathrm{AM} / \mathrm{PG}$ at different concentrations as well as for beech samples treated with the two vinylic monomers. According to these results, the polymerization and formation of resins occurred independently of curing temperature.

Decay resistances of treated and untreated pine wood and beech wood samples are presented in tables 3 and 4 . 
Table 3. Weight losses and standard deviation of pine wood samples subjected to different brown rot fungi.

\begin{tabular}{|c|c|c|c|c|c|c|}
\hline \multicolumn{3}{|c|}{ Treatment } & \multicolumn{4}{|c|}{ Mass loss (\%) } \\
\hline \multirow{2}{*}{ Additive } & \multirow{2}{*}{$\begin{array}{c}\text { Concentration } \\
(\%)\end{array}$} & \multirow{2}{*}{$\begin{array}{c}\text { Temperature } \\
\left({ }^{\circ} \mathrm{C}\right)\end{array}$} & \multicolumn{2}{|c|}{ Unleached blocks } & \multicolumn{2}{|c|}{ Leached blocks } \\
\hline & & & Poria placenta & Coniophora puteana & Poria placenta & Coniophora puteana \\
\hline \multirow{4}{*}{ PGMA } & \multirow{4}{*}{5} & 150 & $34,56 \pm 3,81$ & $38,09 \pm 8,85$ & $40,8 \pm 7,61$ & $41,36 \pm 11,43$ \\
\hline & & 180 & $36,23 \pm 8,10$ & $21,63 \pm 9,90$ & $41,12 \pm 9,54$ & $36,41 \pm 12,16$ \\
\hline & & 200 & $24,57 \pm 1,28$ & $3,06 \pm 2,57$ & $27,64 \pm 6,65$ & $4,08 \pm 1,36$ \\
\hline & & 220 & $4,02 \pm 2,37$ & $0,64 \pm 0,24$ & $7,33 \pm 2,32$ & $0,51 \pm 0,32$ \\
\hline \multirow{4}{*}{ PGMA } & \multirow{4}{*}{10} & 150 & $40,07 \pm 11,65$ & $34,75 \pm 4,78$ & $37,3 \pm 10,41$ & $40,33 \pm 13,98$ \\
\hline & & 180 & $34,42 \pm 8,76$ & $5,3 \pm 1,79$ & $36,85 \pm 6,5$ & $4,15 \pm 1,44$ \\
\hline & & 200 & $4,11 \pm 2,03$ & $1,3 \pm 0,80$ & $5,24 \pm 2,19$ & $2,26 \pm 0,37$ \\
\hline & & 220 & $1,18 \pm 0,98$ & $0,9 \pm 0,39$ & $0,92 \pm 1,16$ & $1,41 \pm 0,81$ \\
\hline \multirow{4}{*}{$\mathrm{AM} / \mathrm{PG}$} & \multirow{4}{*}{5} & 150 & $41,79 \pm 6,65$ & $33,1 \pm 4,98$ & $41,95 \pm 12,09$ & $29,11 \pm 10,11$ \\
\hline & & 180 & $34,1 \pm 8,40$ & $11,75 \pm 8,43$ & $37,03 \pm 11,03$ & $22,75 \pm 5,87$ \\
\hline & & 200 & $22,96 \pm 4,79$ & $3,75 \pm 2,96$ & $25,57 \pm 9,34$ & $4,98 \pm 3,65$ \\
\hline & & 220 & $0,92 \pm 1,20$ & $0,69 \pm 0,96$ & $1,04 \pm 0,70$ & $0,37 \pm 0,63$ \\
\hline \multirow{4}{*}{$\mathrm{AM} / \mathrm{PG}$} & \multirow{4}{*}{10} & 150 & $34,47 \pm 10,54$ & $13,17 \pm 2,68$ & $31,67 \pm 7,62$ & $20,9 \pm 6,74$ \\
\hline & & 180 & $25,18 \pm 9,96$ & $4,61 \pm 2,54$ & $25,74 \pm 6,89$ & $6,2 \pm 2,72$ \\
\hline & & 200 & $5,48 \pm 1,01$ & $2,15 \pm 0,97$ & $11,25 \pm 4,94$ & $2,85 \pm 1,54$ \\
\hline & & 220 & $0,81 \pm 0,09$ & $0,48 \pm 0,78$ & $1,64 \pm 0,06$ & $0,93 \pm 0,23$ \\
\hline \multirow{4}{*}{-} & \multirow{4}{*}{-} & 150 & $45,06 \pm 14,20$ & $40,07 \pm 10,43$ & $49,73 \pm 12,84$ & $42,68 \pm 11,92$ \\
\hline & & 180 & $40,89 \pm 9,16$ & $40,92 \pm 9,92$ & $44,54 \pm 11,43$ & $41,61 \pm 12,23$ \\
\hline & & 200 & $23,98 \pm 7,61$ & $6,57 \pm 2,39$ & $30,6 \pm 11,65$ & $8,12 \pm 3,27$ \\
\hline & & 220 & $11,71 \pm 3,31$ & $3,97 \pm 0,17$ & $30,6 \pm 11,65$ & $5,02 \pm 1,95$ \\
\hline Control & & & $50,41 \pm 11,18$ & $45,76 \pm 7,22$ & & \\
\hline
\end{tabular}

Table 4. Weight losses and standard deviation of beech wood samples subjected to different white rot and brown rot fungi.

\begin{tabular}{|c|c|c|c|c|c|c|}
\hline \multicolumn{3}{|c|}{ Treatment } & \multicolumn{4}{|c|}{ Mass loss (\%) } \\
\hline \multirow{2}{*}{ Additive } & \multirow{2}{*}{$\begin{array}{c}\text { Concentration } \\
(\%)\end{array}$} & \multirow{2}{*}{$\begin{array}{c}\text { Temperature } \\
\left({ }^{\circ} \mathrm{C}\right)\end{array}$} & \multicolumn{2}{|c|}{ Beforeleaching } & \multicolumn{2}{|c|}{ After leaching } \\
\hline & & & Trametes versicolor & Coniophora puteana & Tranetes versicolor & Coniophora puteana \\
\hline \multirow{4}{*}{ PGMA } & \multirow{4}{*}{5} & 150 & $41,68 \pm 6,56$ & $44,74 \pm 2,47$ & $45,01 \pm 12,63$ & $42,38 \pm 3,40$ \\
\hline & & 180 & $38,56 \pm 3,37$ & $40,89 \pm 5,55$ & $45,61 \pm 8,23$ & $42,71 \pm 10,42$ \\
\hline & & 200 & $27,2 \pm 8,06$ & $7,74 \pm 3,45$ & $26,28 \pm 10,88$ & $10,83 \pm 4,86$ \\
\hline & & 220 & $2,57 \pm 1,95$ & $0,19 \pm 0,37$ & $4,63 \pm 0,82$ & $0,85 \pm 0,36$ \\
\hline \multirow{2}{*}{ PGMA } & \multirow{2}{*}{10} & 200 & $20,18 \pm 5,38$ & $3,09 \pm 1,05$ & $21,84 \pm 7,68$ & $6,86 \pm 2,57$ \\
\hline & & 220 & $4,21 \pm 2,73$ & $0,7 \pm 0,65$ & $3,75 \pm 3,51$ & $0,28 \pm 0,32$ \\
\hline \multirow{3}{*}{$\mathrm{AM} / \mathrm{PG}$} & \multirow{3}{*}{5} & 150 & $38,14 \pm 3,53$ & $35,18 \pm 1,73$ & $41,53 \pm 5,42$ & $32,75 \pm 6,5$ \\
\hline & & 180 & $33,56 \pm 5,25$ & $25,84 \pm 4,86$ & $36,02 \pm 5,09$ & $27,51 \pm 7,98$ \\
\hline & & 200 & $10,39 \pm 5,28$ & $5,04 \pm 2,67$ & $12,39 \pm 3,07$ & $3,53 \pm 0,52$ \\
\hline \multirow{2}{*}{$\mathrm{AM} / \mathrm{PG}$} & \multirow{2}{*}{10} & 200 & $12,01 \pm 6,52$ & $1,23 \pm 0,65$ & $12,26 \pm 3,75$ & $2,22 \pm 0,22$ \\
\hline & & 220 & $3,44 \pm 1,98$ & $0,24 \pm 0,86$ & $3,83 \pm 2,7$ & $0,92 \pm 0,45$ \\
\hline \multirow{4}{*}{-} & \multirow{4}{*}{-} & 150 & $55,97 \pm 11,37$ & $55,97 \pm 5,82$ & $55,02 \pm 8,69$ & $48,79 \pm 13,97$ \\
\hline & & 180 & $50,98 \pm 6,35$ & $32,13 \pm 8,63$ & $55,61 \pm 10,41$ & $40,54 \pm 12,36$ \\
\hline & & 200 & $33,23 \pm 8,31$ & $21,18 \pm 3,64$ & $31,84 \pm 7,41$ & $27,25 \pm 9,76$ \\
\hline & & 220 & $4,46 \pm 1,18$ & $0,47 \pm 0,75$ & $3,89 \pm 0,65$ & $0,89 \pm 0,82$ \\
\hline Control & & & $52,99 \pm 8,84$ & $49,54 \pm 9,83$ & - & - \\
\hline
\end{tabular}


Independent of the nature and concentration of the vinylic monomers used, all blocks cured at 150 and $180^{\circ} \mathrm{C}$ present no improvement of durability compared to control samples. Curing at $220^{\circ} \mathrm{C}$ after vinylic monomer impregnation results in significant durability improvement; all samples were minimally attacked by the tested brown rot and white rot fungi. Treatments performed at $200^{\circ} \mathrm{C}$ generally did not improve decay durability, although some decay durability was observed in some cases depending on the vinylic monomer solution, fungal strain and wood species that were used. According to these results, it appears that thermal modification and treatment intensity, which are directly connected to final treatment temperature, are the primary considerations in the improvement of durability. The impregnation of low amounts of vinylic monomers in the wood have no effect on durability as demonstrated by mass losses recorded in samples cured at 150 and $180^{\circ} \mathrm{C}$, similar to those observed for controls. At higher temperature $\left(220^{\circ} \mathrm{C}\right)$, the improvement of durability is similar to that described in the literature during thermal modification (Hakkou et al. 2005, Welzbacher et al. 2007) indicating that a given level of thermodegradation of wood cell wall polymers should be reached to insure durability against fungi.

The effect of different treatments on termite resistance is described in tables 5 and 6 .

Table 5. Weight losses and standard deviation of pine wood samples subjected to termite attack.

\begin{tabular}{|c|c|c|c|c|c|c|}
\hline \multicolumn{3}{|c|}{ Treatment } & \multicolumn{2}{|c|}{ Weight loss (\%) } & \multicolumn{2}{|c|}{ Survival rate (\%) } \\
\hline Additive & $\begin{array}{c}\text { Concentration } \\
(\%)\end{array}$ & $\begin{array}{c}\text { Temperature } \\
\left({ }^{\circ} \mathrm{C}\right)\end{array}$ & Before leaching & After leaching & $\begin{array}{c}\text { Before } \\
\text { leaching }\end{array}$ & $\begin{array}{c}\text { After } \\
\text { leaching }\end{array}$ \\
\hline \multirow{4}{*}{ PGMA } & \multirow{4}{*}{5} & 150 & $12,74 \pm 1,2$ & $15,68 \pm 0,2$ & 74 & 81 \\
\hline & & 180 & $13,58 \pm 0,76$ & $14,74 \pm 1,25$ & 64 & 77 \\
\hline & & 200 & $17,18 \pm 3,01$ & $20,79 \pm 2,77$ & 82 & 68 \\
\hline & & 220 & $4,17 \pm 1,18$ & $8,11 \pm 1,5$ & 23 & 35 \\
\hline \multirow{4}{*}{ PGMA } & \multirow{4}{*}{10} & 150 & $13,19 \pm 1,44$ & $13,45 \pm 1,3$ & 80 & 76 \\
\hline & & 180 & $14,09 \pm 1,72$ & $15,93 \pm 0,68$ & 73 & 84 \\
\hline & & 200 & $9,32 \pm 2,55$ & $13,66 \pm 1,55$ & 29 & 60 \\
\hline & & 220 & $3,95 \pm 0,74$ & $5,57 \pm 2,31$ & 8 & 24 \\
\hline \multirow{4}{*}{$\mathrm{AM} / \mathrm{PG}$} & \multirow{4}{*}{5} & 150 & $9,07 \pm 0,61$ & $9,26 \pm 0,57$ & 57 & 53 \\
\hline & & 180 & $6,24 \pm 1,52$ & $9,55 \pm 2,77$ & 25 & 51 \\
\hline & & 200 & $9,11 \pm 1,02$ & $10,14 \pm 2,57$ & 45 & 45 \\
\hline & & 220 & $5,69 \pm 0,51$ & $6,74 \pm 0,75$ & 4 & 20 \\
\hline \multirow{4}{*}{$\mathrm{AM} / \mathrm{PG}$} & \multirow{4}{*}{10} & 150 & $2,32 \pm 0,58$ & $3,57 \pm 1,12$ & 0 & 6 \\
\hline & & 180 & $2,68 \pm 0,14$ & $4,88 \pm 1,69$ & 0 & 15 \\
\hline & & 200 & $3,03 \pm 0,96$ & $4,59 \pm 1,81$ & 0 & 17 \\
\hline & & 220 & $1,66 \pm 0,46$ & $4,16 \pm 0,22$ & 3 & 5 \\
\hline \multirow{4}{*}{-} & \multirow{4}{*}{-} & 150 & $10,26 \pm 0,71$ & $15,38 \pm 2,43$ & 66 & 79 \\
\hline & & 180 & $15,17 \pm 1,04$ & $17,82 \pm 1,92$ & 78 & 81 \\
\hline & & 200 & $16,64 \pm 0,38$ & $19,65 \pm 3,36$ & 78 & 79 \\
\hline & & 220 & $20,38 \pm 4,87$ & $21,75 \pm 4,02$ & 72 & 80 \\
\hline \multicolumn{3}{|l|}{ Control } & \multicolumn{2}{|c|}{$10,64 \pm 1,19$} & \multicolumn{2}{|c|}{75} \\
\hline
\end{tabular}


Table 6. Weight losses and standard deviation of beech wood samples subjected to termite attack.

\begin{tabular}{|c|c|c|c|c|c|c|}
\hline \multicolumn{3}{|c|}{ Treatment } & \multicolumn{2}{|c|}{ Weight loss (\%) } & \multicolumn{2}{|c|}{ Survival rate (\%) } \\
\hline Additive & $\begin{array}{c}\text { Concentration } \\
(\%)\end{array}$ & $\begin{array}{c}\text { Temperature } \\
\left({ }^{\circ} \mathrm{C}\right)\end{array}$ & Before leaching & After leaching & $\begin{array}{c}\text { Before } \\
\text { leaching }\end{array}$ & $\begin{array}{c}\text { After } \\
\text { leaching }\end{array}$ \\
\hline \multirow{4}{*}{ PGMA } & \multirow{4}{*}{5} & 150 & $10,32 \pm 2,02$ & $9,63 \pm 1,36$ & 88 & 77 \\
\hline & & 180 & $9,26 \pm 0,97$ & $11,41 \pm 1,01$ & 76 & 73 \\
\hline & & 200 & $8,9 \pm 2,29$ & $12,9 \pm 0,86$ & 66 & 79 \\
\hline & & 220 & $5,41 \pm 0,03$ & $8,91 \pm 2,05$ & 27 & 45 \\
\hline \multirow{4}{*}{ PGMA } & \multirow{4}{*}{10} & 150 & $9,27 \pm 0,43$ & $9,16 \pm 1,52$ & 74 & 70 \\
\hline & & 180 & $8,38 \pm 1,61$ & $9,21 \pm 0,43$ & 64 & 72 \\
\hline & & 200 & $7,87 \pm 2,57$ & $10,84 \pm 0,55$ & 63 & 58 \\
\hline & & 220 & $3,38 \pm 2,35$ & $6,45 \pm 2,98$ & 17 & 40 \\
\hline \multirow{4}{*}{$\mathrm{AM} / \mathrm{PG}$} & \multirow{4}{*}{5} & 150 & $6,08 \pm 1,26$ & $6,3 \pm 1,66$ & 53 & 44 \\
\hline & & 180 & $6,32 \pm 1,05$ & $9,76 \pm 2,25$ & 55 & 68 \\
\hline & & 200 & $5,75 \pm 2,16$ & $8,29 \pm 0,43$ & 47 & 61 \\
\hline & & 220 & $3,16 \pm 0,49$ & $3,71 \pm 0,38$ & 11 & 19 \\
\hline \multirow{4}{*}{$\mathrm{AM} / \mathrm{PG}$} & \multirow{4}{*}{10} & 150 & $4,4 \pm 1,19$ & $5,32 \pm 1,01$ & 45 & 54 \\
\hline & & 180 & $3,51 \pm 0,11$ & $5,9 \pm 0,44$ & 32 & 45 \\
\hline & & 200 & $3,55 \pm 1,41$ & $6,9 \pm 3,32$ & 39 & 40 \\
\hline & & 220 & $2,39 \pm 0,24$ & $3,4 \pm 0,49$ & 0 & 17 \\
\hline \multirow{4}{*}{-} & \multirow{4}{*}{-} & 150 & $7,96 \pm 2,15$ & $9,32 \pm 1,05$ & 73 & 73 \\
\hline & & 180 & $8,71 \pm 0,94$ & $11,75 \pm 1,13$ & 73 & 81 \\
\hline & & 200 & $10,26 \pm 2,11$ & $14,74 \pm 1,75$ & 85 & 84 \\
\hline & & 220 & $12,36 \pm 3,09$ & $14,71 \pm 2,21$ & 71 & 75 \\
\hline \multicolumn{3}{|l|}{ Control } & \multicolumn{2}{|c|}{$13,82 \pm 2,14$} & \multicolumn{2}{|c|}{02} \\
\hline
\end{tabular}

Without vinylic monomer impregnation, heat-treated as well as control wood samples were strongly degraded by termites. For both wood species, termite durability decreases with the intensity of thermal modification; samples cured at higher temperatures are generally more susceptible to termite attack than samples cured at lower temperatures. For pine wood, all heat-treated samples present a higher degree of attack than untreated samples, while for beech wood samples, controls were slightly more degraded than heat treated samples. In all cases, the rate of survival of termites at the end of the test is high, indicating that thermally modified samples were not toxic for termites. These results are in good agreement with the results reported by Sivrikaya et al. (2015): thermal modification did not improve durability of naturally non-durable species to termite attack. Similarly, Shi et al. (2007) reported that termite susceptibility of thermally modified aspen, jack pine, and yellow-poplar was comparable to that of untreated controls. At the same time, these authors reported that significantly higher termite attack occurred on thermally modified Scots pine wood compared to untreated wood.

The behaviour of resin-impregnated samples subjected to thermal modification is quite different. Indeed, contrary to non-impregnated samples, termite durability increases as the treatment temperature increases for both wood species. After thermal treatment at $220^{\circ} \mathrm{C}$, resin impregnated samples present a significant durability improvement towards termite attack, with the mass losses being relatively low comparatively in all cases compared to those recorded for controls; the rate of termite survival is weak. The amounts of vinylic monomers in the impregnation solution positively influence the durability of wood; samples treated with a $10 \%$ vinylic monomer solution present the highest durability to termites. After leaching, the termite resistance decreases slightly for most of the treatments but remains better for impregnated heat-treated samples. These results corroborate our previous findings (Salman et al. 2016), suggesting a synergistic effect between chemical and thermal modifications for the improvement of termite durability. Considering the thermal stability of wood and different resins at $220^{\circ} \mathrm{C}$ reported in figure 1, it is assumed that different thermal degradations involving radical formation and possible recombination of these radicals may occur. These reactions may be the source of thermal degradation products presenting toxic properties for termites. Alternatively, the modification of wood cell wall polymers could render the modified wood substrate inadequate as a nutrition source for insects. The fact that durability is maintained after leaching suggests that the modification of the wood cell wall polymer is the primary reasons for the improvement of durability. This result suggests that the treatment may be considered as a non-biocide treatment. However, further experiments are necessary 
to confirm these assumptions. From a more applied point of view, such treatments can be relatively easily applied at industrial scale, vacuum pressure impregnation and thermal modification technologies being already available. Even if the cost of vinylic monomers is difficult to estimate, it can be assumed that utilization of polyglycerol, considered as an industrial by-product, will not be limiting for the development of such treatments. Moreover, wood chemical modification with both polyglycerol derivatives may be considered as "non biocide" treatments as demonstrated by the important weight losses measured for samples cured at $150^{\circ} \mathrm{C}$ after exposure to termites or fungi. At higher temperature, chemical and thermal modifications appeared to act synergistically allowing achieving full protection of wood samples against termites and fungi without the any biocide utilization, which may be of valuable interest for the development of more environmentally wood preservation processes.

\section{CONCLUSIONS}

The results presented in this study confirm our previous findings that impregnation of aqueous solutions of vinylic monomers before thermal modification improves the termite durability of heattreated wood. An impregnation of a 10\% aqueous solution of maleic anhydride/polyglycerol adduct (MA/PG) or polyglycerolmethacrylate (PGMA) followed by thermal modification at $220^{\circ} \mathrm{C}$ improves the durability of the material towards termites, while control samples that were heat treated at $220^{\circ} \mathrm{C}$ were strongly attacked. At the same time, vinylic monomers impregnated in heat-treated samples impart high durability against decay due to the effect of thermal modification. In all cases, similar results were also obtained after leaching, indicating that such treatment would be appropriate for exterior applications. These combinations of chemical and thermal modifications therefore appear useful in termite-infested areas, providing additional application areas for heat-treated products. Termite durability improvements appear to be due to a synergistic effect between chemical and thermal treatments. Further investigations are necessary to study the exact reasons for this durability improvement and modification of wood cell wall polymers in the presence of vinylic monomers during thermal modification.

\section{ACKNOWLEDGEMENTS}

The authors gratefully acknowledge the financial support of the CPER 2007-2013 "Structuration du Pôle de Compétitivité Fibres Grand'Est" (Competitiveness Fibres Cluster). LERMAB is supported by a grant overseen by the French National Research Agency (ANR) as part of the "Investissements d'Avenir" programme (ANR-11-LABX-0002-01, Lab of Excellence ARBRE).

\section{REFERENCES}

Bravery, A.F. 1979. A miniaturised wood-block test for the rapid evaluation of wood preservative fungicides. In: Screening techniques for potential wood preservative chemicals. Proceedings of a special seminar held in association with the 10th annual meeting of the IRG, Peebles 1978. Swedish Wood Preservation Institute Report No. 136. Stockholm.

Chaouch, M.; Petrissans, M.; Petrissans, A.; Gerardin, P. 2010. Utilization of wood elemental composition to predict heat treatment intensity and decay resistance of different softwood and hardwood species. Polym Degrad Stab 95: 2255-2259.

Chaouch, M.; Dumarçay, S.; Petrissans, A.; Petrissans, M.; Gerardin, P. 2013. Effect of heat treatment intensity on some conferred properties of different European softwood and hardwood species. Wood Sci Technol 47(4): 663-673.

NF X 41-569. 2014. Wood preservatives, Laboratory method for obtaining samples for analysis to measure losses by leaching water or synthetic sea water. French standardization committee. 
European committee for standardization. EN. 1986. Wood preservatives - determination of toxic values of wood preservatives against wood destroying basidiomycetes cultured on agar medium. EN 113.

European committee for standardization. EN. 2013. Wood preservatives - Determination of toxic values against Reticulitermes species (European termites) (laboratory method). EN 117.

Esteves, B.M.; Pereira, H.M. 2009. Wood modification by heat treatment - A review. Bioresources 4(1): 370-404.

Gascón-Garrido, P.; Oliver-Villanueva, J.V.; Ibiza-Palacios, M.S.; Militz, H.; Mai, C.; Adamopoulos, S. 2013. Resistance of wood modified with different technologies against Mediterranean termites (Reticulitermes spp.). Int Biodeter Biodegr 82: 13-16.

Gérardin, P. 2016. New alternatives for wood preservation based on thermal and chemical modification of wood - a review. Annals of Forest Science 73(3): 559-570.

Hakkou, M.; Petrissans, M.; Gerardin, P.; Zoulalian, A. 2005. Investigations of the reasons for fungal durability of heat-treated beech wood. Polymer Degradation and Stability 91(2): 393-397.

Militz, H. 2002. Thermal treatment of wood: European processes and their background, The International Research Group on Wood Preservation. IRG/WP 02-40241.

Mburu, F.; Dumarçay, S.; Huber, F.; Petrissans, M.; Gerardin, P. 2007. Evaluation of thermally modified Grevillea robusta heartwood as an alternative to shortage of wood resource in Kenya: Characterisation of physicochemical properties and improvement of bio-resistance. Bioresour Technol 98: 3478-3486.

Roussel, C.; Marchetti, V.; Lemor, A.; Wozniak, E.; Loubinoux, B.; Gerardin, P. 2001. Chemical modification of wood by polyglycerol /maleic anhydride treatment. Holzforschung 55:57-62.

Salman, S.; Petrissans, A.; Thevenon, M.F.; Dumarçay, S.; Perrin, D.; Pollier, B.; Gerardin, P. 2014. Development of new wood treatments combining boron impregnation and thermo modification - Effect of additives on boron leachability. Eur J Wood Prod 72: 355-365.

Salman, S.; Petrissans, A.; Thevenon, M.F.; Dumarçay, S.; Gerardin, P. 2016. Decay and termites resistance of pine blocks impregnated with different additives and subjected to heat treatment. Eur J Wood Prod 74: 37-42.

Shi, J.L.; Kocaefe, D.; Amburgey, T.; Zhang, J.L. 2007. A comparative study on brown-rot fungus decay and subterranean termite resistance of thermally-modified and ACQ-C-treated wood. Holz als Roh und Werstoff 65(5): 353-358.

Sivrikaya, H.; Can, A.; De Troya, T.; Conde, M. 2015. Comparative biological resistance of differently thermal modified wood species against decay fungi, Reticulitermes grassei and Hylotrupes bajulus. Maderas-Cienc Tecnol 17(3): 559-570.

Soulounganga, P.; Marion, C.; Huber, F.; Gerardin, P. 2003. Synthesis of Polyglycerol Methacrylate and its Application to Wood Dimensional Stabilization. J Appl Polym Sci 88: 743-749.

Surini, T.; Charrier, F.; Malvestio, J.; Charrier, B.; Moubarik, A.; Castéra, P.; Grelier, S. 2012. Physical properties and termite durability of maritime pine Pinus pinaster Ait heat-treated under vacuum pressure. Wood Sci Technol 46: 487-501.

Wang, C.L.; Lin, T.S.; Li, M.H. 2002. Decay and termites resistance of planted tree sapwood modified by acetylation. Taiwan Journal of Forest Science 17(4): 483-490.

Welzbacher, C.; Brischke, C.; Rapp, A. 2007. Influence of treatment temperature and duration on selected biological, mechanical, physical and optical properties of thermally modified timber. Wood Material Science and Engineering 2(2):66-77 